\title{
ANALISIS KOMPARASI USAHATANI DAN MARGIN TATANIAGA USAHATANI WORTEL ORGANIK DAN WORTEL NON ORGANIK
}

\author{
L. Saifullah ${ }^{1}$, A. Arsyad ${ }^{1 \mathrm{a}}$ dan H. Miftah ${ }^{1}$ \\ ${ }^{1}$ Program Studi Agribisnis, Fakultas Pertanian, Universitas Djuanda Bogor \\ Jalan Tol Ciawi 1, Kotak Pos 35 Bogor 16720 \\ a'Korespondensi: Apendi Arsyad, Telp : 08129347542 Email: apendi.arsyad@unida.ac.id
}

\begin{abstract}
This study was aimed at assessing and comparing the income, marketing margin, marketing channels, and farmer's share of organic and non organic carrot farming businesses. The study was done in Cisarua District, Bogor Regency from January to September 2014. A t-test was done. Results showed that organic carrot farming had an income which was 5.5\% higher than that of non organic farming. It was also shown that the t-value was -0.247 and t-table of 2.048 indicating that there was no significant income difference in organic and non organic carrot farming businesses. The marketing channel giving profit to organic carrot farming business was channel 1 with a marketing margin of Rp3,500/ $\mathrm{kg}$ and a farmer's share percentage of $50 \%$. Meanwhile, in non organic carrot farming business, marketing channel 4 was the one which gave profit with a marketing margin of Rp15,500/kg and a farmer's share percentage of $22.50 \%$
\end{abstract}

Keywords: farming business, marketing margin, marketing channel, farmer's share

\begin{abstract}
ABSTRAK
Penelitian ini bertujuan untuk mengetahui dan membandingkan pendapatan usahatani pertanian wortel organik dan non organik serta membadingkan marjin tataniaga dan saluran pemasaran serta Farmer's Share dari pertanian wortel organik dan non organik. Penelitian ini dilakukan pada bulan Januari - September 2014 dan bertempat di Kecamatan Cisarua Kab. Bogor.. Penelitian ini disusun menggunakan metode analisis usahatani, marjin tataniaga, saluran pemasaran, Farmer's Share dan Uji-t untuk perbandingannya. Hasil yang diperoleh dari analisis adalah pertanian organik memiliki nilai pendapatan lebih besar 5,51\% dibanding non organik. Analisis perbandingan dengan Uji-t mendapatkan nilai t-hitung sebesar -0,247 dan t-tabel sebesar 2,048 yang artinya secara signifikan tidak terdapat perbedaan pendapatan dari pertanian wortel organik dengan non organik walupun ada perbedaan angka pada pendapatan.. Saluran pemasaran yang menguntungkan petani wortel non organik yaitu pada saluran 1 dengan nilai marjin tataniaga sebesar Rp 3.500/Kg dengan persentase $50 \%$ dan Farmer's Share sebesar 50\%, sedangkan pertanian non organik pada saluran 4 dengan marjin tataniaga sebesar Rp 15.500/Kg dengan persentase Farmer's Share sebesar 22,50\%.
\end{abstract}

Kata kunci : Usahatani, marjin tataniaga, saluran pemasaran,Farmer' Share 


\section{PENDAHULUAN}

Indonesia merupakan negara agraria yang banyak menghasilkan produk pangan pertanian khususnya hortikultura. Tanaman hortikultura ini terdiri dari tanaman buah-buahan, tanaman sayursayuran dan tanaman hias. Wortel merupakan salah satu tanaman hortikultura dari jenis sayur-sayuran.

Hasil produksi tanaman wortel nasional (2012) mengalami penurunan dari 526,917 ton pada tahun 2011 menjadi 458,392 ton pada tahun 2012 (Badan Pusat Statistik, 2013) sehingga membuat penurunan juga pada pendapatan daerah yang memproduksi tanaman wortel. Penurunan produksi wortel ini berdampak juga di daerah Jawa Barat dimana Provinsi Jawa Barat merupakan salah satu provinsi di Indonesia yang menghasilkan produk pertanian hortikultura khususnya tanaman wortel. Jumlah Produksi wortel di Provinsi Jawa Barat sebesar 115,296 ton pada tahun 2012. Di Provinsi Jawa barat memiliki 14 kabupaten yang memproduksi tanaman wortel salah satunya adalah Kabupaten Bogor. Produksi wortel di Kabupaten Bogor sebesar 2,036 ton (Departemen Pertanian, 2013).

Mulai adanya kesadaran masayarakat akan dampak dari penggunaan bahan-bahan kimia pada proses budidaya pertanian membuat masyarakat menjadi kembali kepada gaya hidup sehat atau kembali ke alam (Back to nature) yang telah menjadi tren baru masyarakat saat ini. Berdasarkan Badan Penelitian dan Pengembangan pertanian tahun 2002 bahwa komoditi yang bisa dijadikan untuk menjadi produk organik adalah tanaman pangan padi, hortikultura sayuran, perkebunan, rempah dan obat serta peternakan. Di daerah Kabupaten Bogor saat ini sudah melakukan usahatani organik khususnya di Kecamatan Cisarua yang dimana lokasi Kecamatan Cisarua merupakan dataran tinggi yang berada di daerah puncak gunung mas Kabupaten Bogor. Tanaman sayuran organik yang dibudidayakan oleh petani di Kecamatan Cisarua salah satunya adalah tanaman wortel organik dan non organik.

Wortel organik oleh petani biasanya dijual langsung ke konsumen akhir atau dijual ke perusahaan yang bergerak pada tanaman sayuran organik di sekitar daerah Kecamatan Cisarua, tetapi wortel non organik biasanya para petani langsung menjual ke konsumen di pasar dan ada juga yang diolah dari tanaman wortel tersebut menjadi makanan ringan seperti kerupuk wortel maupun dodol wortel. Harga wortel organik yaitu sekitar Rp 18.000/kg sedangkan harga wortel non organik sebesar Rp $7.000 / \mathrm{kg}$ sehingga sangat jauh perbedaan harga wortel organik dengan non organik (Dinas Pertanian Tanaman Pangan Provinsi Jawa Barat, 2013).

Margin yang cukup jauh antara wortel non organik dengan wortel yang organik membuat keuntungan margin petani wortel semakin tinggi, dengan kata lain ketika keuntungan petani wortel meningkat maka perekonomian keluarga petani wortel dan kesejahteraan petani wortel akan meningkat. Pada saat ini masyarakat secara umum sudah dikenali dengan makanan sehat salah satunya makanan yang berlebelkan organik, dengan semakin meningkatnya pencerdasan masyarakat tentang organik maka semakin tinggi permintaan wortel organik yang berdampak pada meningkatnya pendapatan usahatani petani wortel organik. Penelitian ini bertujuan untuk mengetahui dan membandingkan pendapatan usahatani pertanian wortel organik dan non organik serta membadingkan marjin tataniaga dan saluran pemasaran serta Farmer's Share dari pertanian wortel organik dan non organik.

\section{BAHAN DAN METODE}

\section{Pertanian Non Organik}

Pertanian non organik adalah pertanian yang menggunakan faktor-faktor pelancar produksi seperti pupuk, pestisida 
dan obat-obatan lain yang mengandung unsur kimiawi yang bermanfaat untuk meningkatkan hasil produksi yang tinggi dan membuat produk terlihat bagus oleh konsumen, dengan pertanian non organik ini maka bahan kimiawi memiliki peranan penting dalam produk hasil pada sistem pertanian non organik. Hal ini yang menyebabkan petani menggunakan bahan kimia dengan berlebihan yang berdampak negatife pada lingkungan dan kesehatan tubuh manusia ketika mengkonsumsi produk tersebut (Kusumah, 2004).

\section{Pertanian Organik}

Pertanian Organik merupakan sistem pertanian yang keseluruhan dan terpadu dengan cara mengoptimalkan kesehatan dan produktivitas agroekosistem secara alami secara alami, sehingga menghasilkan pangan dan serat yang cukup, berkualitas dan berkesinambungan. IFOAM ( International Federation of Organic Agriculture Movements) menjelaskan pertanian organik adalah pertanian holistik yang mendukung dan mempercepat biodiversity, siklus biologi dan aktivitas biologi tanah. Sertifikasi produk organik yang dihasilkan, penyimpanan, pengolahan, pasca panen, dan pemasaran harus sesuai standard yang ditetapkan oleh badan standarisasi (Rachmiyanti, 2009)

\section{Sistem Tataniaga}

Menurut Limbong dan Soitorus (1987, pada dasarnya tataniaga memiliki pengertian yang sama dengan pemasaran. Para ahli telah mendefinisikan pemasaran atau tataniaga sebagai sesuatu yang berbeda- beda sesuai sudut pandang mereka. Pemasaran atau tataniaga dapat didefinisikan sebagai suatu proses manajerial dimana individu atau kelompok di dalamnya mendapatkan apa yang mereka butuhkan dan inginkan dengan menciptakan, menawarkan, mempertukarkan produk yang bernilai dengan pihak lain.
Margin merupakan istilah yang digunakan untuk menyatakan perbedaan harga yang dibayar kepada penjual pertama dan harga yang dibayar oleh pembeli terakhir (Hanafiah dan Saefudin, 1983). Besarnya marjin tataniaga dipengaruhi oleh jalur tataniaga komoditas yang bersangkutan. Marjin tataniaga diperoleh oleh lembaga-lembaga tataniaga hasil dari fungsi tataniaga, harga penjualan, harga pembelian di setiap tingkat lembaga tataniaga, biaya tataniaga dan keuntungan (Limbong dan Sitorus, 1987).

\section{Waktu dan Tempat}

Penelitian ini dilaksanakan pada Januari-September 2014 bertempat di Kecamatan Cisarua Kabupaten Bogor Provinsi Jawa Barat. Lokasi penelitian merupakan wilayah kerja dari Badan Penyuluhan Pertanian, Perikanan dan Kehutanan (BP3K) Kecamatan Cisarua. Lokasi dan tempat penelitian yang dilakukan peneliti merupakan hasil dari survey dan diskusi dengan BP3K. Responden yang diambil untuk usahatani wortel organik yaitu Kelompok Tani Godong Organik yang terletak di Desa Tugu Utara, sedangkan untuk usahatani wortel non organik responden yang diambil adalah Kelompok Tani Sawah Lega yang terletak di Desa Citeko. Pengambilan sampel dilakukan dengan cara sensus dengan jumlah petani wortel organik berjumlah 15 orang dan petani wortel non organic 15 orang.

Pengumpulan data dilakukan dengan menggunakan data primer dan data sekunder. Data primer diperoleh dengan cara wawancara, sedangkan data sekunder diperoleh melalui dokumen badan-badan pemerintah yang terkait dengan data yang sesuai dengan penelitian. Metode analisis yang digunakan peneliti adalah metode analis usahatani yang terdiri atas analisis data, analisis titik impas dan analisis R/C rasio. Selain itu, analisis yang digunakan adalah analis margin saluran pemasaran, Farmer's share dan analisis perbandingan 
pendapatan usahatani dengan menggunakan uji-t.

\section{Analisis Pendapatan Usahatani}

Analisis ini bertujuan untuk menggambarkan keadaan sekarang dari kegiatan usahatani dan keadaan yang akan datang. Analisis usahatani dapat digunakan sebagai bantuan untuk mengukur berhasil tidaknya suatu kegiatan usahatani (Hernanto, 1988)

Analisis pendapatan usaha dihitung dengan rumus :

Keterangan :

$$
\mathrm{I}=\mathrm{TR}-\mathrm{TC}
$$

$\mathrm{I}=$ Income (pendapatan)

$\mathrm{TR}=$ Total Revenue (penerimaan total)

$\mathrm{TC}=$ Total Cost (biaya total)

\section{Analisis Titik Impas dan Rasio R/C}

Analisis Titik Impas (BEP) adalah alat analisis yang menunjukan pada tingkat penjualan berapakah yang mengakibatkan kadaan usaha tidak mengalami keuntungan atau kerugian (impas) (Musyadar, 2005).

Pendapatan bersih dapat dihitung dengan menggunakan analisis pendapatan usaha. Analisis pendapatan usaha yaitu selisih antara pengeluaran dan penerimaan selama periode tertentu. Alasan meggunakan analisis R/C ini yaitu apakah dengan menggunakan analisis ini dapat dilaksankan atau tidak tergantung pada keputusan dari pihak yang akan melakukan usaha

\section{Analisis Margin Saluran Tataniaga}

Besarnya marjin tataniaga dipengaruhi oleh jalur tataniaga komoditas yang bersangkutan. Marjin tataniaga diperoleh oleh lembaga-lembaga tataniaga hasil dari fungsi tataniaga, harga penjualan, harga pembelian di setiap tingkat lembaga tataniaga, biaya tataniaga dan keuntungan tataniaga dapat dirumuskan sebagai berikut (Limbong dan Sitorus, 1987) ;

$$
\mathrm{Mi}=\mathrm{Psi}-\mathrm{Pbi}
$$

Keterangan ;

$\mathrm{Mi}=$ marjin tataniaga di tingkat ke-i
Psi $=$ harga jual pasar di tingkat $\mathrm{ke}-\mathrm{i}$

$\mathrm{Pbi}=$ harga beli pasar di tingkat ke-i

$$
\mathrm{Mi}=\mathrm{Li}+\pi \mathrm{i}
$$

Keterangan ;

$\mathrm{Li}=$ biaya lembaga pemasaran pada tingkat ke-i

$\pi \mathrm{i}=$ keuntungan lembaga pemasaran pada tingkat ke-i

Dari kedua persamaan diatas, maka diperoleh :

$$
\text { Psi }-\mathrm{Pbi}=\mathrm{Li}+\pi \mathrm{i}
$$

Keuntungan Lembaga pemasaran pada tingkat ke $-\mathrm{i}$

$$
\pi \mathrm{i}=\mathrm{Psi}-\mathrm{Pbi}-\mathrm{Li}
$$

\section{Analisis Farmer's Share}

Farmer's Share digunakan untuk membandingkan harga yang dibayar konsumen terhadap harga produk yang diterima petani (Limbong dan Sitorus, 1987). Besarnya nilai bagian petani dapat dihitung berdasarkan rumus :

$$
\text { Farmer's Share }=(\mathrm{Pf} / \mathrm{Pr}) \mathrm{x} 100 \%
$$

Keterangan :

$\mathrm{Pf}=$ harga di tingkat petani

$\operatorname{Pr}=$ harga yang dibayarkan konsumen akhir

\section{Analisis Perbandingan Pendapatan Usahatani (Uji-t)}

Salah satu penggunaan statistika adalah untuk menguji hipotesis perbedaan pendapatan usahatani yang dilakukan oleh petani wortel karena pada proses usahatani yang dilakukan memiliki perbedaan sistem usahatani yaitu secara organik dan non organik. Metode yang digunakan dalam uji perbandingan pada tingkat pendapatan usahatani wortel organik dan wortel non organik yaitu dengan cara metode uji-t. Alasan karena perbedaan antara nominal usahatani pertanian wortel yang dilakukan secara organik maupun non organik berbeda tetapi belum tentu secara statistik. Mungkin saja kedua pendapatan usahatani yang dilakukan dengan sistem yang 
berbeda tersebut berbeda karena kebetulan saja (Nazir, 2005). Karena itu maka harus dilakuki uji perbedaan terlebih dahulu untuk melihat beda antara pendapatan usahatani wortel organik dan wortel non organik benar-benar berbeda secara signifikan. Salah satu metode uji perbandingan ini dilakukan dengan menggunakan uji-t.

Sebelum menggunakan uji-t maka harus dicari terlebih dahulu standar error dari beda yaitu dengan cara :

$$
S \mathrm{x}_{1}-\mathrm{X}_{2}=\overline{\frac{S S_{1}+S S_{2}}{n_{1}+n_{2}-2}} \frac{1}{n_{1}+n_{2}}
$$

Keterangan :

$\mathrm{SS}_{1}=$ sumsquare dari sampel pertanian wortel organik

$\mathrm{SS}_{2}=$ sumsquare dari sampel pertanian wortel non organik

$\mathrm{n}_{1}=$ besar sampel pertanian wortel organik

$\mathrm{n}_{2}=$ besar sampel pertanian wortel non organik

$\mathrm{Sx}_{1}-\mathrm{X}_{2}=$ standar error dari beda

Sumsquare tidak lain dari :

$$
\mathrm{SS}=X_{i}^{2}-\frac{X_{i}^{2}}{n}
$$

Keterangan :

$\mathrm{Xi} \quad=$ Pengamatan variabel ke-i

$\mathrm{n} \quad=$ besar sampel

SS = sumsquare

Hipotesis yang dirumskan dalam penelitian ini yaitu

$\mathrm{H} 0$ : $\mathrm{A}=\mathrm{a}$, dengan hipotesis alternative $\mathrm{Ha}: \mathrm{A} \neq \mathrm{a}$

Keterangan :

$\mathrm{A}=$ Pendapatan Usahatani Wortel Organik

$\mathrm{a}=$ Pendapatan Usahatani Wortel Non Organik

Setelah hipotesis telah dirumuskan maka dicari perbedaannya dengan menghitung uji statistiknya (uji-t) yaitu dengan rumus :

$$
t=\frac{x_{1}-x_{2}}{S x_{1}-x_{2}}
$$

Keterangan :

$\mathrm{X} 1=$ rata-rata pendapatan usahatani wortel organik

$\mathrm{X} 2$ = rata-rata pendapatan usahatani wortel non organik

\section{PEMBAHASAN}

Berdasarkan analisis usahatani pada Tabel 1 diperoleh perbedaan hasil antara usahatani wortel organik dan usahatani wortel non organik., baik dari segi pendapatan, titik impas maupun $\mathrm{R} / \mathrm{C}$ rasio. Berdasarkan analisis pendapatan usahatani, pendapatan usahatani wortel organik lebih besar $5,51 \%$ dibandingkan pendapatan usahatani wortel non organik. Besar pendapatan yang diperoleh petani wortel organik adalah sebesar Rp 3.746.502 Harga wortel organik sebesar Rp 3.000,sampai dengan $\mathrm{Rp} 4.500,-/ \mathrm{Kg}$, sedangkan harga wortel non organik sebesar $\mathrm{Rp}$ 1.000,- sampai dengan Rp 3.500,-/Kg. Produktivitas yang dihasilkan oleh petani wortel organik yaitu sebesar 6.250,00 $\mathrm{Kg} / \mathrm{Ha}$ dengan penerimaan sebesar $\mathrm{Rp}$ 19.375.000,-/Ha, sedangkan produktivitas yang dihasilkan oleh petani wortel non organik yaitu sebesar 8.442,86 Kg/Ha dengan penerimaan sebesar $\mathrm{Rp}$ 20.442.857,14,-/Ha.

Biaya produktivitas yang dikeluarkan oleh petani wortel organik yaitu sebesar Rp 15.628.497,46/Ha, sedangkan biaya produktivitas yang dikeluarkan oleh petani wortel non organik sebesar Rp 18.265.532,54,-/Ha. Dari hasil tersebut maka diperoleh pendapatan usahatani wortel organik sebesar $\mathrm{Rp} \quad 3.746 .502,54 / \mathrm{Ha} / \mathrm{tahun}$, sedangkan pendapatan usahatani wortel non organik yaitu sebesar Rp 2.177.324,60,-/Ha/tahun.

Rasio R/C yang diperoleh dari hasil penelitian ini adalah usahatani wortel organik memeliki R/C rasio sebesar 1,24, sedangkan $\mathrm{R} / \mathrm{C}$ rasio dari usahatani wortel non organik sebesar 1,12. Nilai titik impas (BEP) yang untuk usahatani wortel organik yaitu sebesar $1.831,32 \mathrm{Kg} / \mathrm{Ha}$ atau sama 
dengan Rp 824,09,-/Ha, sedangkan nilai titik impas dari usahatani wortel non organik sebesar 954,10 Kg/Ha atau sama dengan Rp 954,10,-/Ha. Nilai titik impas dari usahatani wortel non organik lebih kecil dibandingkan dari nilai titik impas petanian wortel organik dikarenakan hasil produktivitas yang diperoleh petani wortel organik lebih kecil dari hasil produktivitas yang dihasilkan oleh petani non organik. Analisis usahatani pertanian wortel organik dan anorganik dapat dilihat pada Tabel 1.

Tabel 1. Analisis Usahatani Pertanian Wortel Organik Dan Anorganik

\begin{tabular}{|c|c|c|c|}
\hline No & Uraian & $\begin{array}{l}\text { Pertanian Wortel } \\
\text { Organik (Rp/Ha) }\end{array}$ & $\begin{array}{c}\text { Pertanian Wortel Non } \\
\text { Organik (Rp/Ha) }\end{array}$ \\
\hline & Jumlah Panen & $6.250 .00 \mathrm{Kg}$ & $8.442 .86 \mathrm{Kg}$ \\
\hline & Total Penerimaan & $19.3750 .000,00$ & $20.442 .857,14$ \\
\hline & Biaya & & \\
\hline & Biaya Tetap & & \\
\hline 1 & Sewa Lahan & $375.000,00$ & $750.000,00$ \\
\hline \multirow[t]{3}{*}{2} & Saprodi (penyusutan) & $2.426 .558,93$ & $149.861,11$ \\
\hline & Total Biaya tetap & $2.801 .558,93$ & $899.861,11$ \\
\hline & Total Biaya Rata-rata & 448,25 & 106,58 \\
\hline 1 & Biaya Variabel & & \\
\hline 2 & Benih & $582.779,22$ & $1.472 .619,05$ \\
\hline 3 & Pupuk & $4.000 .000,00$ & $2.479 .052,38$ \\
\hline \multirow[t]{10}{*}{4} & Pestisida & 0.00 & $520.190,48$ \\
\hline & Tenaga Kerja & $8.244 .159,31$ & $12.893 .809,52$ \\
\hline & Total Biaya Variabel & $12.826 .938,54$ & $17.365 .671,43$ \\
\hline & Total Biaya Variabel & & \\
\hline & Rata-rata & 2052,31 & 2056,85 \\
\hline & Total Biaya & $15.628 .497,46$ & $18.265 .532,54$ \\
\hline & Keuntungan & $3.746 .502,54$ & $2.177 .324,60$ \\
\hline & $\mathrm{R} / \mathrm{C}$ & 1.24 & 1.12 \\
\hline & BEP KG & $1.831,32$ & 954,10 \\
\hline & BEP Rp & 824,09 & 339,02 \\
\hline
\end{tabular}

Hasil analisis perbandingan yang dilakukan terhadap biaya produktivitas dan pendapatan usahatani dari usahatani wortel organik dan usahatani wortel non organik menggunakan uji-t. Hasil analisis perbandingan antara biaya produksi yang dikeluarkan oleh petani wortel organik maupun petani wortel non organik menghasilkan nilai t-hitung sebesar -2,51 dan t-tabel sebesar 2,05. Hasil dari analisis perbandingan pada biaya produksi tersebut bahwa H0 ditolak dan H1 diterima, sehingga secara signifikan hipotesa menyatakan bahwa terdapat perbedaan biaya produksi antara usahatani wortel organik dengan usahatani wortel non organik.
Analisis perbedaan yang didapatkan dari hasil uji-t pada pendapatan usahatani usahatani wortel organik dan usahatani wortel non organik menghasilkan t-hitung sebesar -0,247 dengan t-tabel sebesar 2,048. Hal ini menyatakan bahwa $\mathrm{H} 0$ diterima dan $\mathrm{H} 1$ ditolak, secara signifikan hipotesa dari hasil tersebut adalah tidak terdapat perbedaan antara hasil pendapatan petani wortel organik maupun pendapatan petani wortel non organik secara statistika.

Saluran pemasaran yang dihasilkan dari penelitian tersebut yaitu terdapat 7 saluran pemasaran yang terdiri atas 3 saluran pemasaran pada usahatani wortel non organik dan 4 saluran pemasaran pada usahatani wortel non organik. Pada saluran 
usahatani wortel non organik yang menguntungkan petani yaitu pada saluran 1 dengan nilai farmer's share sebesar 50\% dan marjin tataniaga sebesar $\mathrm{Rp} 3.500,-/ \mathrm{Kg}$ serta dengan saluran yang lebih pendek dari saluran lainnya. Pada saluran pemasaran wortel organik yang menguntungkan petani yaitu pada saluran 4 dengan nilai farmer's share sebesar 22,5\% dengan marjin tataniaga sebesar $\mathrm{Rp}$ 15.500,-/Kg. Pada saluran 4 ini juga merupakan saluran yang paling pendek dalam saluran pemasaran lainnya pada usahatani wortel non organik.

\section{KESIMPULAN DAN IMPLIKASI KEBIJAKAN}

\section{Kesimpulan}

Berdasarkan hasil dan pembahasan yang dilakukan dalam penelitian ini maka dapat disimpulkan hal-hal sebagai berikut :

1. Pendapatan yang dihasilkan oleh usahatani wortel organik lebih menguntungkan $5,51 \%$ dibandingkan dengan usahatani wortel non organik. Pendapatan yang diperoleh petani wortel organik sebesar $\mathrm{Rp}$ 3.746.502,54 /Ha, sedangkan pendapatan yang didapatkan oleh petani wortel non organik yaitu sebesar Rp 2.177.324,60 / Ha. R/C Ratio dari pertanian organik yaitu sebesar 1,24 yang artinya setiap $\mathrm{Rp} 1,-$ yang dikeluarkan oleh petani wortel organik akan mendapatkan keuntungan sebesar $\mathrm{Rp}$ 1,24,-, sedangkan R/C Ratio dari pertanian wortel non organik sebesar 1.12. BEP dari pertanian wortel organik sebesar 1.831,32 $\mathrm{Kg} / \mathrm{Ha}$ atau sama dengan $\mathrm{Rp} 824,09$ / Ha, sedangkan BEP dari pertanian wortel non organik yaitu sebesar 954,10 Kg atau sama dengan Rp 339,02 / Ha.

2. Usahatani wortel di Kecamatan Cisarua memiliki 7 saluran pemasaran yang terdiri atas 4 saluran pemasaran usahatani wortel organik dan 3 saluran pemasaran pertanian wortel non organik. Saluran pemasaran yang menguntungkan petani wortel organik yaitu saluran pemasaran dengan nilai Farmer's Share paling besar yaitu $22,5 \%$. Saluran pemasaran pada pertanian wortel non organik yang lebih menguntungkan petani adalah pada saluran pemasaran 1 dengan nilai Farmer's Share paling besar yaitu 50\%. Perbandingan Farmer'share yang didapat oleh petani wortel non organik lebih besar dari Farmer's Share yang didapat oleh petanik wortel organik yaitu sebesar $50 \%: 22,5 \%$. Perbandingan tersebut menyatakan bahwa petani wortel non organik mendapatkan persentase harga lebih besar dibandingkan petani wortel non organik. Hal tersebut diakibatkan jalur pemasaran yang dilakukan petani wortel organik lebih panjang, sehingga persentase yang diperoleh petani semakin kecil.

\section{Implikasi Kebiakan}

Pendapatan Petani wortel organik di Kecamatan Cisarua lebih menguntungkan dibandingkan petani wortel non organic, akan tetapi Farmer's Share yang diperoleh lebih kecil. Hal tersebut diakibatkan jalur pemasaran yang lebih panjang, untuk itu peneliti menyarankan supaya petani wortel organik memperpendek jalur pemasaran serta melakukan packaging sendiri, dan

BP3K sebagai lembaga yang manaungi petani termasuk petani wortel, sebaiknya melakukan pelatihan packing yang baik sesuai standar perusahaan sehingga petani akan memperoleh harga jual yang lebih tinggi dari perusahaan.

\section{Daftar Pustaka}

Badan Pusat Statistik. 2013. Produksi Sayuran di Indonesia 1997-2012. www.bps.go.id.

Departemen Pertanian. 2013. Produksi Wortel Provinsi tahun 2010-2019. www.deptan.go.id.

Dinas Pertanian Tanaman Pangan Jawa Barat. Info Harga Sayuran tanggal 20 September 2013.

Hanafiah A , Saefuddin M. 1983. Tataniaga Hasil Perikanan. UI Press. Jakarta

Hernanto F. 1988. Ilmu Usaha Tani. Penebar Swadaya. Jakarta 
Kusumah SJ. 2004. Analisis Perbandinagn Usahatani Dan Pemasaran Antara Padi Organik dan Padi Non Organik. [Skripsi]. Program Studi Eksitensi Manajemen Agribisnis Institut Pertanian Bogor. Bogor

Limbong WM dan Sitorus P. 1987. Pengantar Tataniaga Pertanian. Bahan Kuliah.Jurusan Ilmu-ilmu Sosial Ekonomi Pertanian Fakultas Pertanian Institut Pertanian Bogor. Bogor
Musyadar A, Muslihat EJ. 2005. Manajemen Keuangan Agribisnis. Sekolah Tinggi Penyuluhan Pertanian. Bogor

Nazir M. 2005. Metode Penelitian. Ghalia Indonesia. Bogor

Rachmiyanti I. 2009. Analisis Perbandingan Usahatani Padi Oragnik Metode System of Rice Intensification (SRI) dengan Padi Konvensional. [Skripsi]. Fakultas Pertanian Institut Pertanian Bogor. Bogor 